\title{
The Influence of The Problem Based Learning and Attitudes Towards Learning Outcomes For Mathematics
}

\author{
Antonious Yohan ${ }^{1}$, Mustaji ${ }^{2}$, Suryaman ${ }^{3}$ \\ ${ }^{1,3}$ Teknologi Pendidikan, Universitas PGRI Adi Buana Surabaya \\ ${ }^{2}$ Teknologi Pendidikan, Universitas Negeri Surabaya
}

\section{Edcomtech}

Jurnal Kajian

Teknologi Pendidikan

Volume 4, No 1, April 2019

Halaman 1-7

Submitted 12-12-2018

Accepted 01-03-2019

Corresponding Author

Antonious Yohan,

antonarmanta@gmail.com

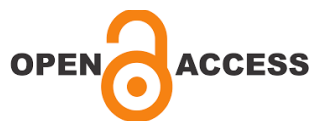

\begin{abstract}
Abstrak
Penelitian ini bertujuan untuk (1) untuk mengetahui perbedaan antara hasil belajar siswa yang mengikuti PBL dan pembelajarsan konvensional, (2) untuk mengetahui perbedaan antara siswa yang memiliki hasil belajar dengan sikap belajar lebih tinggi dan lebih rendah (3) untuk mengetahui interaksi antara model pembelajaran dan sikap belajar terhadap hasil belajar. Penelitian ini menggunakan jenis penelitian kuantitatif. Implementasi observasi model data Data dan hasil angket belajar sikap siswa yang dianalisis di Indonesia deskriptif kuantitatif dengan menentukan skor dan persentase yang diperoleh setiap aspek diamati. Hasil penelitian menunjukkan bahwa: (1) terdapat perbedaan antara hasil belajar siswa yang mengikuti Pembelajaran Berbasis Masalah dan pembelajaran konvensional. (2) ada perbedaan antara siswa yang memiliki hasil belajar dengan sikap lebih tinggi dan lebih rendah (3) ada interaksi antara model pembelajaran dan sikap terhadap hasil belajar.
\end{abstract}

Kata Kunci: Pembelajaran, sikap, Problem Based Learning 


\section{INTRODUCTION}

Indonesia currently has a variety of problems in the country. One of the problems is the quality of national education Indonesia which is still low. According to the results of research conducted The third International mathematichs and Science Studies (TIMSS), mathematics education in Indonesia is currently at rank 34 out of 38 countries in asia and interest in learning mathematics of NEM students Indonesia is very low (Ruseffend, 2003:3). In this era of globalization, the qualified human resources will be the main object of that one nation can compete. With respect to the foregoing, formal education is one of the rides in building qualified human resources. Up to now, there is a wide range of models used in the study one of the models developed and is often used in teaching and learning activities is model-based learning problems. Learning based on problem (problem based learning) is an approach to students to develop thinking skills and solve problems, learn authentic adult role as well as being a student independent. Problem-based learning model (problem based learning) is an approach to students to develop the skills of thinking skills and solve problems, learn authentic adult role as well as being a student independent. Problembased learning Model is a model of learning which is done with the awarding of stimulus in the form of problems then do troubleshooting by students is expected to increase the skills of students in the achievement of the learning material.

Learning based on the issue are not designed to help teachers provide much information to the students, but the problembased learning, developed to help students develop the ability to think, the solution problems and intellectual skills, learning the various roles of adults through their involvement in the actual experience and learning to become an independent. Formulation issues (1) Whether there are differences between the learning outcomes of students who follow the LBC and conventional learning, (2) whether there is a difference between learning outcomes learning attitude of high and low, (3) is there any interaction between the model and the attitudes towards learning the results of the study. problem or problems in mathematics is in the form of mathematical problems, which in the end will be exposed to students. Not all of the matter may be referred to a problem or issue. A problem is said to be not "problem ' for a person when it is reasonably easy to solve. A soluble problem is usually due to a problem is often studied and technical in nature. type reserved memory (a matter which usually asks students to identify or mention mathematical facts, definitions, or statements of a theorem/ postulate). And the type of procedural matter (matter that requires the completion of the form step by step procedure which in this case students just entering numbers or numbers into formulas, theorems, or algorithm), included into the Group of reserved routine (routine Saturday problems), IE problems are easy and less able to improve students ' ability in solving problems. Loaded questions to uncover students ' ability in solving problems. Loaded questions to uncover the problem solving capability must be reserved at least meet the following criteria (1) the question of challenging mind (challenging), (2) Reserved is not automatically a known way (nonroutine) revealed that problems with open type including problems that are suitable for improving the ability to resolve problems. The question of open type in question is the type of problem solving strategies problem is not visible on the matter. Problems of this type requires ability see patterns and make conjectures.

Problem-based learning (PBL) is a way of composing and teaching a learning process using the issue as a stimulus/arousal and the focus is more on the activity of students. The learning process using problem-based learning is usually more of a problem than begins with the mastery of Science (Boud, 1991:14). There are 4 important feature of Problem-based learning, according to Baron (2003:1) among others are: (1) Use problems in the real world, (2) Learning focuses on problem solving, (3) learning objectives determined by the students. (4) The teacher acts as a facilitator. From the initial concept 
of PBL can be described as a learning situation that is triggered by the existence of a problem in real life. By using the question as the start of a process of learning, learners do the learning process through interaction in a study group to solve the question posed at the beginning of the study. Learning occurs when students are trying to solve the problems/issues together.

According to (Nurwidasa, 2008:81) there are three important elements in the implementation of learning by using PBL, the elements: (1) Cases or issues that have not been structured in detail (2) learner-centered Learning (Student Centred Learning) (3) Cooperative Learning in small groups. Cases or problems that have not been structured in detail is at the core of the usage of PBL in learning. The case used is a case that is not structured, contain a deeper understanding of the complex, open to various solutions and reflect real life. The case or problem can be taken from a variety of sources, including from magazine articles, from a text book, or from other sources obtained from the internet. That should be considered is that cases that problem it should be selected that can learning to find information-information pertaining to these problems in order to understand the nature and motivated to solve the problem (Nurwidasa, 2008:81).

\section{METHOD}

This research uses the method of observation aims to collect data by means of observing the activities of students during the learning session. This observation is done to obtain data on barriers to learning math in the classroom. The observations were performed with the barriers noted in the observation sheet. This interview aimed to find out what obstacles related to model-based learning problems, and to verify the data of the test results of the study provided the researcher to the students in advance. Interest in student learning data obtained through a questionnaire sheet handed out to all students after the whole process of actions completed. This test aims to collect data on students understanding of the material about trigonometry. This test method is used as a research instrument in the collection of data to pinpoint student learning results after following the process of learning in a learning cycle.

The shape of the required data in the study will be divided into two used to assess students' interest and to assess student learning outcomes. (1) Student attitude, form data is data that is used to assess the interest of students towards agebra in the form of operating material description-description description as well as an assessment of the process of the parties involved in this research. (2) The data results of student learning, student learning outcomes Data obtained from test results of the initial capabilities given before learning of mathematics model of learning problems and learning test results are given at the end of learning mathematics by problem-based learning model. In addition also used individual quiz twice which is useful to measure the students in understanding the material studied. (3) data model-based learning with learning problems. Learning outcome data with LBC as seen from the observation sheet results from each meeting the learning in the classroom. From the observation sheet can be obtained from the results of the implementation of the studybased learning problems during the session.

\section{RESULT AND DISCUSSION}

\section{Result}

Problem-based learning (PBL) is a way of composing and teaching a learning process using the issue as a stimulus/arousal and the focus is more on the activity of students. The learning process using problem-based learning is usually more of a problem than begins with the mastery of science. The results of the implementation model observations of based learning problem goes well. This is apparent from the observations the observer gave a high score on every aspect. Implementation of learning by using PBL can deliver enthusiastic learning is good for the students at the two schools. attitude is the trend in subject accept or reject an object based on the assessment of that object as the object is valuable or worthless. In the attitude there are aspects 
of cognition, affection, aspect and the aspect. Moreover stated that the attitude is the degree of positive or negative feelings directed against psychological objects, for example, sentences symbols symbol, motto, ideas can be distinguished into the idea of positive and negative ideas. The attitude was always with regard to an object and the attitude toward this object is accompanied by a positive or negative feelings. People have a positive attitude towards an object of value in the landscape, and will behave negatively to object that he deems are not valued and are also hurting. This attitude then underlying and push towards acts that relate to one another.

In the mathematical field of study the attitude of a person towards mathematics as seen from to know or learn more from to better engage or involve yourself in various activities related to math. Based on these notions can be defined that the involvement of students in the lessons and activities related to math can reflect attitudes towards mathematics. While the opinion the attitude means a tendency to accept or reject an object based on the assessment of the object as it useful/valuable (positive attitude) or not useful/valuable negative attitude. Then the attitude of students toward mathematics means the tendency to accept or reject the mathematical lessons based on against mathematics as not useful/valuable (negative attitudes towards mathematics) the results of the study are deeds patterns, values, understanding-understanding, attitudes, skills and appreciation. The results of the study as an ability owned student after he gained experience of learning. The results of the study are changes that occur as a result of learning activities that have been carried out by individuals. From some sense of learning outcomes which have been expressed before, it can be concluded that the results of learning is a change that occurs in individuals both in terms of the deed, values, understandingunderstanding, attitudes, appreciations, and skills after experiencing the learning experience. From the observations that have been made, the researchers noticed that in the process of learning, teachers use a method for delivering lecture materials on students. The opportunity given to the students to participate in the process of learning not much. The attitude of students in learning mathematics implementation is still low to tackle this type of problem is given by the teacher.

Students just listen and take note of the explanations of the teacher, then working on the given question. Occasional teacher asked about material that is learned at students, but the answer is just a few students or students replied in unison. Based on interviews with the teacher, when the teacher gives the question, then ask the students to work on in front of the class, only a few students are willing and other students who do not want to participate. The researchers also did a test instrument test results of a study that will be used. From the results of interviews with students 6 students on the knowable that interest students high mathematics learning in following using PBL. Proven when students answer questions from investigators, they are interested with the given problem and felt challenged to learn, they feel closer to mathematical problems in the life of the vernacular of the day, they love to learn independent and creative thinking, they are also attracted by the large number of discussion groups each learning in class because they can exchange ideas and opinions of fellow.

\section{Discussion}

Problem-based learning (PBL) is a way of composing and teaching a learning process using the issue as a stimulus/arousal and the focus is more on the activity of students. The learning process using problem-based learning is usually more of a problem than begins with the mastery of science. attitude is the trend in subject accept or reject an object based on the assessment of that object as the object is valuable or worthless. In the attitude there are aspects of cognition, affection, aspect and the aspect of . Moreover stated that the attitude is the degree of positive or negative feelings directed against psychological objects, for example, sentences symbols symbol, motto, ideas can be distinguished into the idea of 
positive and negative ideas. The attitude was always with regard to an object and the attitude toward this object is accompanied by a positive or negative feelings. People have a positive attitude towards an object of value in the landscape, and will behave negatively to object that he deems are not valued and are also hurting. This attitude then underlying and push towards acts that relate to one another. In the mathematical field of study the attitude of a person towards mathematics as seen from to know or learn more from to better engage or involve yourself in various activities related to math. Based on these notions can be defined that the involvement of students in the lessons and activities related to math can reflect attitudes towards mathematics. While the opinion the attitude means a tendency to accept or reject an object based on the assessment of the object as it useful/valuable (positive attitude) or not useful/valuable negative attitude. Then the attitude of students toward mathematics means the tendency to accept or reject the mathematical lessons based on against mathematics as not useful/valuable (negative attitudes towards mathematics). The results of the study are the patterns of deeds, values, understanding-understanding, attitudes, skills and appreciation. The results of the study as an ability owned student after he gained experience of learning. The results of the study are changes that occur as a result of learning activities that have been carried out by individuals. From some sense of learning outcomes which have been expressed before, it can be concluded that the results of learning is a change that occurs in individuals both in terms of the deed, values,

Understanding-understanding, attitudes, appreciations, and skills after experiencing the learning experience. Student learning outcomes (1) Are Classical, in classical, student learning outcomes are having good results. Data analysis shows that the results of classical learning already achieved the target or standard research class action set out in the study that is at least $75 \%$ of students who complete the KKM. (2) The average value of a class, the results of the data analysis of the results obtained by learning that the average value has reached the target or standard class action research targeted in research that is of 75 .

The difference in the results of the learning of students who follow the LBC and conventional analysis indicated with SPSS

\section{Univariate Test}

\begin{tabular}{lccccc}
\hline & $\begin{array}{c}\text { Sum of } \\
\text { Squares }\end{array}$ & df & $\begin{array}{c}\text { Mean } \\
\text { Square }\end{array}$ & F & Sig \\
\hline Contrast & 154.364 & 1 & 154.364 & 4.088 & 0.038 \\
Error & 2114.709 & 56 & 37.763 & & \\
& & & & & \\
\hline
\end{tabular}

\begin{tabular}{lccccc}
\multicolumn{6}{c}{ Univariate Test } \\
\hline & $\begin{array}{c}\text { Sum of } \\
\text { Squares }\end{array}$ & df & $\begin{array}{c}\text { Mean } \\
\text { Square }\end{array}$ & F & Sig \\
\hline Contrast & 154.364 & 1 & 154.364 & 4.088 & 0.038
\end{tabular}

The $\mathrm{F}$ tests the effect of Metode. This test is based on the linearly independent pairwise comparisons among the estimated marginal means. $\mathrm{HO}: \mu 1=\mu 2=\mu 3 \mathrm{H} 1$ : there is a difference between a conventional Output with PBL SPSS: Sig: 0.038 , because Gis 0.038 $\mathrm{HO}$ is rejected then the $0.05<$, so there is a difference between the learning outcomes of students who follow the LBC with conventional learning The difference in the results of the learning of students who follow the LBC and conventional $d$ indicated with SPSS

\section{Univariate Test}

Dependent

Variable:Hasil

\begin{tabular}{lccccc}
\hline & $\begin{array}{c}\text { Sum of } \\
\text { Squares }\end{array}$ & df & $\begin{array}{c}\text { Mean } \\
\text { Square }\end{array}$ & F & Sig \\
\hline Contrast & 14.870 & 1 & 14.870 & 0.394 & 0.033 \\
Error & 2114.709 & 56 & 37.763 & & \\
& & & & &
\end{tabular}

The $\mathrm{F}$ tests the effect of kategori motivasi. This test is based on the linearly independent pairwise comparisons among the estimated marginal means.

Test of Anava HIGH SCHOOL learning attitude $\mathrm{HO}: \mu_{1}=\mu_{2}=\mu_{3} \mathrm{H} 1$ : there is a difference between learning outcomes learning attitude and lace High Output SPSS: Sig: 0.0330 .033 
Sig Because $0.05 \mathrm{HO}$ is rejected then <, so there is a difference between the learning outcomes of students who the attitude of his studies with low learning attitude

The interaction between the learning model and attitudes towards learning outcomes by using SPSS is indicated as follows: Test Data correlation H0: $\rho=0: \rho \mathrm{H} 1$ $\neq 0$, the Output of SPSS: 0.0070 .007 For Sig Sig $\mathrm{HO}$ is rejected then the $0.05<$, so there's an interaction Tara model learning and attitudes towards learning outcomes.

\section{SUMMARY AND ADVICE}

\section{Summary}

The conclusion that can be drawn from this study (1) the difference between the Learning Outcomes of students who Follow the conventional Learning and PBL learning is designed with more mature produce better learning. Students are getting most out of doing the learning process. PBL learning model can improve the learning results of students in learning mathematics material (2) the difference between the attitude of Learning Outcomes Learning high and low. The overall result of the student response against the statements in the questionnaire sheet learning attitude of students and of the results of the interviews with the students showed that the learning attitude of students with a learning model of PBL learning outcomes there is a difference between the learning attitude of higher and lower. This led to any difference between learning outcomes learning attitude of higher and lower. This is apparent from the results of the analysis of the attitude of students the message is high. The student was pleased with the learning of mathematics in particular of algebraic operations on the material for learning model that used to lead to the understanding of the students against the concepts studied independently with the guidance of a teacher. (3) The interaction between the Learning Model and attitude towards the results of the Learning Interaction models of learning and attitudes towards learning outcomes, there are interactions that affect student learning outcomes on trigonometry. This is apparent from the results of the analysis using SPSS in class control and experimental classes.

\section{Suggestions}

The benefits of the research to benefit from the results of this research provide more opportunities for students actively in the learning process. One of them by applying a model of problem-based learning. Teachers can use can use model-based learning problems in math material to another. Further research To more research, we recommend looking for an alternative learning models variansi PBL, so students can focus more on when to follow the learning process. And in research, should be organised so that all of the subject can follow a series of research activities are complete and the material used is the material intact, not just taken part so students can understand the material in intact.

\section{REFERRENCES}

Adhetia Martyanti. (2016) . Keefektifan pendekatan problem posing dan problem solving dalam pembelajaran kalkulus II. Jurnal riset pendidikan matematika. Vol.3,N0.2

Arikunto, Suharsimi. (2006). Prosedur Penelitian Suatu Pendekatan Praktek. Jakarta: Rineka Cipta.

Arikunto, Suharsini, dkk, (2006). Penelitian Tindakan Kelas. Bumi Aksara. Jakarta

Arikunto, S. (2006). Prosedur Penelitian. Jakarta: PT Rineka Cipta.

Asmawi, Zainul. Pengukuran, Tes dan Evaluasi Hasil Belajar, Jakarta : PAU, 1992.

Baron. (2004). Psikologi Sosial.Erlangga. Jakarta

Borg and Gall. (1983). Education Research: An Introduction 4th edition. New York: Longman.

David Boud \& Graham Feletti. (1991). The Chalenge of problem Based Learning. New York : St.Martin's.

Departemen Pendidikan Nasional, (2003). Undang-undang Nomor 20 Tahun 2003, tentang Sistem Pendidikan Nasional, Jakarta: Dediknas.

Depdiknas, (2004). Kerangka Dasar Kurikulum 2004. Jakarta : Depdiknas. 
Depdiknas. (2006). Permendiknas No 22 Tahun 2006 tentang Standar Isi Untuk Satuan Pendidikan Dasar dan Menengah. Jakarta: Ditjen Dikdasmen Depdiknas.

Dilek.S \& Merve.C. (2015). Mathematical problem solvin variables that affect problem solving success.International research in education. Vol.3,No.2

Kuan chen tsai. (2017). Creative problem solving styles and personality types in macau college students. Global journal of educational studies. Vol.8, No.2

Muh.Fajarudin.A. (2017). Investigating student difficulties on integral calculus based on critical thinking aspects. Jurnal riset pendidikan matematika. Vol.4,No.2

Markus Palobo. (2016). Keefektifan problem solving dan guided inquiry dalam setting TAl ditinjaui dari prestasi belajar, kemampuan berpikir kritis, dan kedisiplinan diri. Jurnal riset pendidikan matematika. Vol.3,No2

Muhamad.F \& Heri.R. (2014). Keefektifan PBL dan IBL ditinjau dari prestasi belajar, kemampuan representasi matematis, dan motivasi belajar. Jurnal riset pendidikan matematika. Vol 1,Pages: 227-240

Nurwidasa. (2008). Pengaruh Kedisiplinan Belajar,Gaya belajar dan minat baca

Rusmono. (2012). Strategi pembelajaran dengan problem based learning itu perlu untuk meningkatkan profesionalitas guru. Bogor : Ghalia Indonesia

Ruseffendi. (2006). Pengantar Kepada Membantu Guru Mengembangkan Kompetensinya dalam Pengajaran Matematika. Bandung: Tarsito

Slameto. (2001). Belajar dan faktor-faktor yang mempengaruhinya. Jakarta : Bumi Aksara

Suharsimi Arikunto. (2005). Dasar-dasar Evaluasi Pendidikan. Jakarta : Bumi Aksara.

Tahani.A \& Ahmad.H. (2016). The extent to which the first three grades teachers use problem solving approach in teaching sciences and the effective factors in it at jerash district in Jordan.International journal of education. Vol.8, No.2 